\title{
Hong Kong SAR, China and BRI's Globalization
}

\author{
Jean A. Berlie \\ Education University of Hong Kong, Hong Kong, China \\ Email: berliehn@yahoo.fr
}

How to cite this paper: Berlie, J.A. (2021) Hong Kong SAR, China and BRI's Globalization. Open Access Library Journal, 8: e7580.

https://doi.org/10.4236/oalib.1107580

Received: May 25, 2021

Accepted: June 27, 2021

Published: June 30, 2021

Copyright (C) 2021 by author(s) and Open Access Library Inc.

This work is licensed under the Creative Commons Attribution International License (CC BY 4.0).

http://creativecommons.org/licenses/by/4.0/

(c) (i) Open Access

\begin{abstract}
This article looks at the differences and similarities between globalization and the role of China on globalization in particular for the Hong Kong Special Administrative Region of China (HKSAR). Design/methodology/approach of this article is based on research, reading, interviews on globalization during many years and the author published a book on the BRI in 2020. China's Globalization called OBOR in 2013, was replaced by the BRI (Belt and Road Initiative) in 2017. This is a key global new Silk Road not only for China and Asia, but also for Hong Kong Special Administrative Region (China), Macau (China), Australia, Africa, South-East Asia in particular, and countries in Latin America such as Bolivia and Venezuela. The new globalization of the century called Belt and Road Initiative (BRI) is a unique and global way to boost the economy of China and reinvent the Maritime and Land Silk Road of China which is 2000 years old. The role of the HKSAR linked with the Greater Bay Area is not well known. Macau also plays a role because it was the first point of globalization in the sixteenth century. China, the second economy of the world is really a global country, and Chinese are numerous in all continents. Chinese Internet role is also important. Hong Kong SAR is part of the Greater Bay Area. China is currently developing the new globalization of the century called BRI.
\end{abstract}

\section{Subject Areas}

Sociology, Law

\section{Keywords}

BRI, Economy, Globalization, Hong Kong SAR, India, Macau, OBOR, Silk Road

\section{Introduction}

China's New Silk Road is clearly a modernized BRI including maritime and land 
trade, new infrastructures, movement of cultural influences, and ideas. The differences and similarities between globalization and the role of China on globalization are essential to understand the relationship of the BRI and Hong Kong. Hong Kong Special Administrative Region of China (HKSAR) and the Greater Bay Area, are an essential industrial and economic part of South China.

The current definition of Chinese globalization includes OBOR initiated in 2013 by President Xi Jinping and called BRI in 2017.

Macau had an early globalization in the sixteenth century, however, Hong Kong SAR is now a more global city associated with the Western World and Shenzhen SEZ, but Macau SAR is socio-politically closer to Beijing.

Historically, Hong Kong in 1839 did not start smoothly with British opium trade which was stopped by the Imperial Commissioner Lin Zexu. A blockade followed and trade restarted in 1841 with the cession of Hong Kong and the reopening of the trade in Canton nowadays called Guangzhou [1].

Following the past reforms of Deng Xiaoping, absolutely essential for the future of China, and the creation of Special Economic Zones (SEZs), in 2013, President Xi Jinping launched his idea of the new global vision of China. Globalization is a concept more Western oriented, but in 2017, China's Belt and Road Initiative (BRI) has created a new type of globalization.

One of the important definitions of globalization is the socio-political process in which the constraints of geography on economic, political, social and cultural arrangements recede [2]. This article considers the positivity of globalization and describes the ongoing global trend towards freer flow of trade and investment [3].

Yet, we cannot forecast the total success of China for this BRI in Hong Kong; the world has five continents. The BRI is a geopolitical turning point. On 7 April 2017 President Xi Jinping met Donald Trump in the USA. However, President Trump has good international links with the Prime Minister Narendra Modi. India who is culturally and economically influent, and in principle accepts to be a part of the BRI and welcome to support China's globalization named Belt and Road Initiative. India is part of the world which is fully accepting international negotiation and arbitration and China is progressing.

Since the First of July 1997, Hong Kong is part of China according to its Basic Law. In HKSAR, with the exceptional three days visit of President Xi Jinping on the 29, 30 June and 1 July 2017 for the 20th Anniversary of Hong Kong's return to China, local politics and relationship with the Central Government was the issue. Developing the economy through globalization and BRI is also an important issue; a closer successful economic relationship Mainland-HKSAR may create a more harmonious political situation. For Beijing, diverting the attention of the Chinese of Hong Kong from politics is not an easy task to put in place. The President of China, Xi Jinping, understood that during an important commemorative event, the visit to the Grand Bridge linking Hong Kong to Zhuhai and Macau is politically useful. An enlarged and economic success of the Pearl River Delta- 
called now the Greater Bay Area-is creating a new economic dynamism in this important Southern region of China.

The question is that "One Belt One Road" is too visible and will not immediately attract the interest of the Chinese of Hong Kong, unless it becomes more operative in the Greater Bay Area. In 2017 OBOR became the Belt and Road Initiative (BRI). The Pearl River Delta was part of it with Hong Kong and Macau SAR and became the Greater Bay Area which includes Hong Kong and Macau SARs, two Special Economic Zones (SEZs), and 9 cities in Guangdong Province including Guangzhou.

China emerged as a global economic power [4] and the Greater Bay Area is the fastest-growing city cluster in China. It has the potential to become a pioneer in a China-US regional cooperation project. Rex Tillerson was the first US secretary of state who openly reaffirmed President Xi's proposal of a new type of major power relations. He also acknowledged the importance of working on a long-term commitment to chart the course of the development of US-China relations [5].

\section{Globalization}

The literature on globalization is prodigious. Early globalization started in the 16th century in Macau which was buying silver in Mexico to be able to trade silk. China did not accept another currency to buy silk. So, from America to Europe, Africa and Asia (Manila), Macau traders-also linked to the Island of Timorbecame the first globalized actors of the world. This socio-economic phenomenon was called "early globalization" [6].

Historically linked with the Roman Empire, the "New Silk Road" is 2000 years old, the BRI is the unique key global land and maritime Road. We need to quote Marco Polo (1254-1324) who met his protector the Emperor of China, Kubilai Khan, in 1275 who gave him a gold tablet to travel in the Empire. Polo managed to reach Venice in 1295.

In 2021, the BRI includes China, Asia, Hong Kong Special Administrative Region, Macau, Australia, Africa, South-East Asia in particular, but also countries in Latin America such as Bolivia and Venezuela. Table 1 explains how many countries are already involved. The BRI, above regions and countries, is the unique such global project between 2017 and the present day. Belt and Road Initiative developed in my last book, in 2020, needs initiative, excellent management of the risks, creativity, international governance and ethics.

Globalization as we know it in the 21 st century became a word in fashion in the 1990s.

The Economist argued that globalization following O'Rourke's research in 2002, started earlier than the 19th century, and regressed with a world's economic crisis in 2007. It is certain that the internet, civil aviation and the international trade centered on container-ships contributed efficiently to popularize the use of the current concept of globalization. For China, the aim is mainly to be 
Table 1. Countries supporting the BRI.

\begin{tabular}{ccc}
\hline Region & Number & Population \\
\hline East Asia \& Pacific & 25 & $2,130,668,702$ \\
South Asia & 6 & $468,595,896$ \\
Europe \& Central Asia & 35 & $579,552,394$ \\
Middle East & 10 & $215,935,689$ \\
Africa & 46 & $1,254,574,279$ \\
Latin America \& Caribbean & 18 & $145,683,187$ \\
Total, (62.5\% of World) & 140 & $4,795,010,147$ \\
World & $7,673,533,974(2019) 7.8$ billion $(2020)$ \\
\hline
\end{tabular}

Source: https://www.brixsweden.org/wp-content/uploads/2021/01/BRI_Members_2021_Updated.pdf (accessed 23 May 2021).

connect internationally in economic and strategic terms for the development of the Belt and Road-New Silk Road. China at present accepts the principle of arbitration and there are positive changes concerning Chinese arbitration policy, but its main court is the Supreme People's Court of the People's Republic of China. It is favorable for the development and international acceptation of the BRI that now arbitration is more accepted along the BRI.

China is particularly oriented towards ASEAN and to develop its excellent relationship with ASEAN. According to the Jakarta Post, on 5 April 2021, an important meeting took place in Jakarta. Brunei and Malaysia agreed that ASEAN will hold a special summit to address the Myanmar situation, as harsh crackdowns on anti-coup protests. Over 500 people have been killed.

The meeting was held at the ASEAN secretariat in the capital of Indonesia. Sultan Hassanal Bolkiah of Brunei, chairman of ASEAN and Malaysian Prime Minister Muhyiddin Yassin voiced concerns over Myanmar. The two leaders expressed "serious concern on the ongoing crisis in Myanmar and the rising number of fatalities" and urged all parties to seek a peaceful solution, was suggested earlier by the Indonesian President Joko Widodo who wanted a peaceful solution to the Myanmar crisis. The ASEAN joint statement was principally done by both countries Malaysia, Brunei.

During that period was celebrated the 30th anniversary of establishment of the diplomatic relations between China and Brunei. Most of the countries of ASEAN, including Timor Leste, are in close relations with China concerning economic, political, security and socio-cultural development.

Politics itself is also global and permeated by transnational networks. China's Global Internet Ambitions also help to develop the BRI. BRI and Internet Plus plan and China's diplomatic engagement with ASEAN on cyber issues has deepened through the set-up of bilateral institutions designed to foster cooperation and investment in digital connectivity, Internet governance, and e-commerce. 
Chinese Internet companies too have bet big on the region through investments and partnerships with Southeast Asian companies in e-commerce, digital finance, gaming, and cloud computing, among other things. This presents a number of economic opportunities for the region to leapfrog stages in digital connectivity and technology but also poses political and strategic challenges to ASEAN that need to be acknowledged and addressed sooner rather than later [7]. China has no limits concerning globalization and is an observer country and active in the maritime navigation in the Artic Region which is also a part of the BRI's domain with the help of Russia, but in concurrence with Canada and the USA.

United Nations (UN), IMF and other international agencies alter the dynamics of both states and civil society. Trade disputes are a problem arising from division of labor in the globalized world [8].

During the year 2013, 21 countries joined OBOR, in 2015 a total of 59 countries were included, in 201768 countries joined the Belt and Road Initiative which was included in the country's Constitution, in 2019102 countries including Italy the country of Marco Polo were part of China's Global project. To understand the importance of the BRI, the following Table 1 demonstrates the current global success of the New Silk Road and the growing number of countries supporting the BRI.

\section{HKSAR and Globalization}

To be global fits the conception of Hongkongers as homo economicus initiated in the Joint Declaration and the Basic Law and reiterated back to the public as the "authentic" Hong Kong identity "boostrap capitalist". The motive behind the 1997 return to China was political but also economic. Hong Kong firms were responsible for two-third of direct foreign investment in China [9]. Simon Lee Siu-po, teaching at the Chinese University of Hong Kong thinks that Hong Kong will continue to be a role model and the mainland need to catch up. On 1 July 2017, China's Government, represented by President Xi Jinping, received the oath of the new Chief Executive Carrie Lam during the 20th Anniversary of the handover to China.

However, the significant key idea of the Silk Road was also important. The new bridge Hong Kong-Zhuhai-Macau, is one of the longest of the world. This Bridge has not directly promoted the globalization of the HKSAR, but greatly facilitate the communication between Hong Kong, the Pearl River Delta and Macau. The giant bridge avoid bottlenecks which slow down the traffic. The BRI needs much more than that it links countries and regions. Globalization is much more than a bridge, but a giant bridge gives a good image to China.

The planned visit of the President Xi Jinping-the architect of China's globalization-during his rather long stay in Hong Kong promotes in itself the BRI. This project for the Province of Guangzhou is useful because it links a very industrial region of South China with Hong Kong and for example ASEAN. Xi wants the success of its global project and infrastructure Prime Minister Li Ke- 
qiang pledged that Hong Kong and the Hong Kong Zhuhai Macao Bridge has promoted the globalization of the Hong Kong Special Administrative Region. It plays a bigger role in the nation's development in boosting its role as a global financial, shipping, trade center [10]. The other mission of Xi Jinping early July was also to promote development in the HKSAR and the construction of the grand bridge Hong Kong-Zhuhai-Macau. Part of the exceptional three-days visit of the president was to observe the progress of the construction of this essential link to ensure the development of Maritime and Land Silk Road and Greater Bay Area. HKSAR in terms of economical openness and dynamism had in 2016 a GDP of US\$1.39 trillion making it the fifth largest economy in Asia. Xie Feng says that Hong Kong has an irreplaceable role in ensuring the Greater Bay Area reaches its full potential. HKSAR is one of the world's freest economy and its container harbor will contribute to the economic demands of the Greater Bay Area [10]. HKSAR has no Foreign Affairs power, but has 30 consulates and more than 30 International Chambers of Commerce. In August 2017, the Ministry of Foreign Affairs of Hong Kong organized an international conference to promote the Silk Road and the internationalization of the Greater Bay Area. The author was present when on 23 October 2017 the French Macau Chamber of Commerce (FMCC) was launched in Macau, but it was existing since 2008 under the name FMBA.

The Belt ad Road Initiative (BRI) in HKSAR seems not accepted everywhere yet, despite a favorable improvement of innovation in recent years mentioned by Ho Lok-sang, teaching at Chu Hai College. During her maiden policy address on 11 October 2017, the Chief Executive Carrie Lam Cheng Yuet-ngor wanted to boost innovation and technology.

The completion of the giant bridge between Hong Kong and Macau will certainly contribute to improve the image of HKSAR and will demonstrate that innovation is working well [11]. However, globalization is not always welcome, economists worry whether deregulation produce greater wealth at the price of increased inequality? Political scientists worry that their field might vanish along with their favorite object, the nation-state [12].

Thomas Friedman, Samuel Huntington, Robert Kaplan, and Dinesh Souza are not accepted everywhere despite their popularity among specialists of globalization. Does anti-globalization work in HKSAR? Globalization or anti-globalization sometimes work hand by hand. Is it possible to imagine that the youth movement in HKSAR uses the ideas of Pierre Bourdieu to impose more democracy in the Special Administrative Region of China? [13]. Contrary to Singapore which uses the power of the information society to shape the society, Hong Kong according to Nick Moore has no formal policies, but is instead developed and shaped by market forces alone [14]. Could we say that an alternative should be a better version of post-1968 capitalism, liberal capitalism dominates is it evident to sometimes turn back to Marx? On the one hand, the ideological climate was dominated by the collapse of the Soviet Union and its East European extensions. 
While the most widely noticed intellectual trends took different forms-for example, Fukuyama's announcement of the End of History. Now, at best, the choice was between different kinds of capitalism, we have to adjust American capitalism and Chinese capitalism launched by Deng Xiaoping. It is useful because it could help to find a solution to cure the social discomfort of the Hong Kong society, and in particular the Youth who want drastic change impossible because the Basic Law is a sort of constitutional document valid until 2047 [15]. The current dream of the youth is not realistic, we have to study patiently the development of the Great Bay in the Pearl River Delta; the reality is to try to push the project of the giant bridge which is becoming operational between Hong Kong and Macau SARs via Zhuhai, it needs also the participation of 2 SEZs and 9 cities in Guangdong Province [16]. A neo-liberalist approach of the economy, closer to the Singaporean system with an economy of happiness, based on human initiatives and will, making allowance in its calculations for the costs in suffering and the profits in fulfilment that are ignored by the "strictly economic cult of productivity and profitability". In an enquiry of popularity of the Chief Executive Carrie Lam, the author found that 60 percent of the interviewees are still satisfied, but 15 percent are not satisfied and this includes many youth, 25 percent do not want to answer yes or no or do not know what to say. Still 15 percent is an important number when the great majority is necessary to develop such a Bay, the new Mega-Region of the Pearl River Delta. In 2021 more than 140 countries already gave their support to One Belt One Road (Table 1). The essential development of the Silk Road needs the will and the heart of the inhabitants for this huge project which needs the participation and the good will of the youth as well as the participation of all the society to succeed.

It seems that India may collaborate more concerning China's Belt and Road. In Hong Kong to develop the Silk Road toward India, the support of most of the 28 Indian Associations is needed. Better than other associations in India linked to information society, they know how to deal with the Chinese and what to say in India concerning the Maritime Silk Road to convince. Of course their communication language is English, but a certain number of Indian permanent residents speak Cantonese and may use Cantonese language to communicate with the Chinese of Hong Kong, such as Wang Zhimin, former Director of the Liaison Office of the Central People's Government in the Hong Kong Special Administrative Region (HKSAR) and MSAR, who also speaks Cantonese. Speaking the same language helps. Mr Wang met officially the Chief Executive Carrie Lam on 28 September 2017. However, in 2018 Wang was replaced, but this will not change the mind of the Hongkongers concerning a closer collaboration to accept the Belt and Road. Luo Huining is a senior member of the Chinese Communist Party and is the present Director of the Liaison Office of the Central People's Government in Hong Kong and Macau and he uses Putonghua, which is commonly used among the cadres representing Beijing in Hong Kong.

Equally the author thinks that globally it is useful to promote the BRI. How- 
ever, the new term BRI. 2. seems to be an Australian invention to promote or not the BRI. In 2019, reported by Yves Tiberghien and the Australian Institute of International Affairs, more important for the BRI is the second high-level of the Belt and Road not yet well developed. Another good example is the Forum in Beijing, that took place between 25 and 27 April 2019. It was attended by 5000 delegates from 150 countries, including top ministers from 5 out of seven G7 countries, only was missing the USA and Canada. Most of Asia and G20 countries were present. The summit marked the signing of 126 bilateral memorandum of understandings (MOUs) with separate countries.

Reported by Xinhua and Global Times on 1.12.2020, the two-day Belt and Road Summit organized by the Hong Kong Special Administrative Region government which started online, focused on Belt and Road opportunities and the global economic recovery after the COVID-19 pandemic. "The Belt and Road Initiative and globalization will advance in tandem and complement each other, with highquality Belt and Road cooperation making the new type of globalization more open, inclusive, balanced and beneficial to all". The Belt and Road Initiative and globalization will advance in tandem and complement each other, with highquality cooperation making the new type of globalization more open, inclusive, balanced and beneficial to all. Government officials and business leaders from countries and regions along the Belt and Road discussed the opportunities the Belt and Road brings. However, this needs to be seriously discussed to really progress.

In 2020, China signed the Regional Comprehensive Economic Partnership trade agreement with 15 countries and the Comprehensive Agreement on Investment with the European Union. More important for the world and BRI in June 2021 China-US relations, the two economic chiefs Liu He, Janet Yellen exchanged virtual talk. This exchange includes discussion of macro-economic situation and importance of bilateral relationship, according to Xinhua. There is certainly a need for economic policy coordination between the world's two largest economies [17].

\section{Limitation of Research}

Globalization is unlimited, but limitations exist for placing research findings in context, interpreting the validity of the scientific work, and ascribing a credibility level to the conclusions of published research.

In comparison with the BRI, Hong Kong is a limited space which was rather prestigious financially; but the Shanghai Financial Center, opened lately on 28 August 2008 is a unique place in Mainland China able to be compared at present to Hong Kong which as a major financial since 1970 emerged as one of the main global financial centers located in East Asia. At present after New York and London comes Shanghai Financial Center before Hong Kong. The Hong Kong suffered. "The overall ratings of financial centers have yet to recover to the levels in 2019". The HK Government Report pointed out that this reflects the continuing 
uncertainty brought about by international trade, the impact of the COVID-19 pandemic and the geopolitical environment [18].

It is impossible to change the local legal rules of the Basic Law called "One Country, Two Systems" valid from July 1997 to July 2047?

\section{Epilogue}

The giant Hong Kong-Zhuhai-Macau Bridge is a first step toward a new globalization of the Greater Bay Area, and there is no institution to decide that this bridge is a part of the Belt and Road Initiative. The great success to realize successfully this fantastic infrastructure task impose respect, it was launched by President Xi Jinping. History is marching toward a globalized world [19]. The HKSAR, the mega bridge's main investor, will fully embrace the huge project of the new Silk Road has to be integrated into China's global projects. China's Ministry of Foreign Affairs in HKSAR, 2 SEZs, 9 cities in the industrialized Guangdong Province and Hong Kong and Macau SARs will promote tripartite cooperation among Guangdong, Hong Kong, Shenzhen and Belt and Road to ensure better development and international investors who will seize the opportunities [20]. To develop the BRI global project, the Chief Executive Carrie Lam has also to win the hearts of businessmen and Hong Kong permanent residents, to develop the Greater Bay Area and fully include the giant bridge into the global project. New enquiries and fieldwork on the role of Chinese and Indian associations in the Special Administration Region of China will develop motivation and promote Hong Kong's globalization. HKSAR is already linked to 一带一路 (One Belt, One Road) and the new Silk Road called Belt and Road Initiative (Figure 1).

The Belt and Road Initiative: Six Economic Corridors Spanning Asia, Europe and Africa

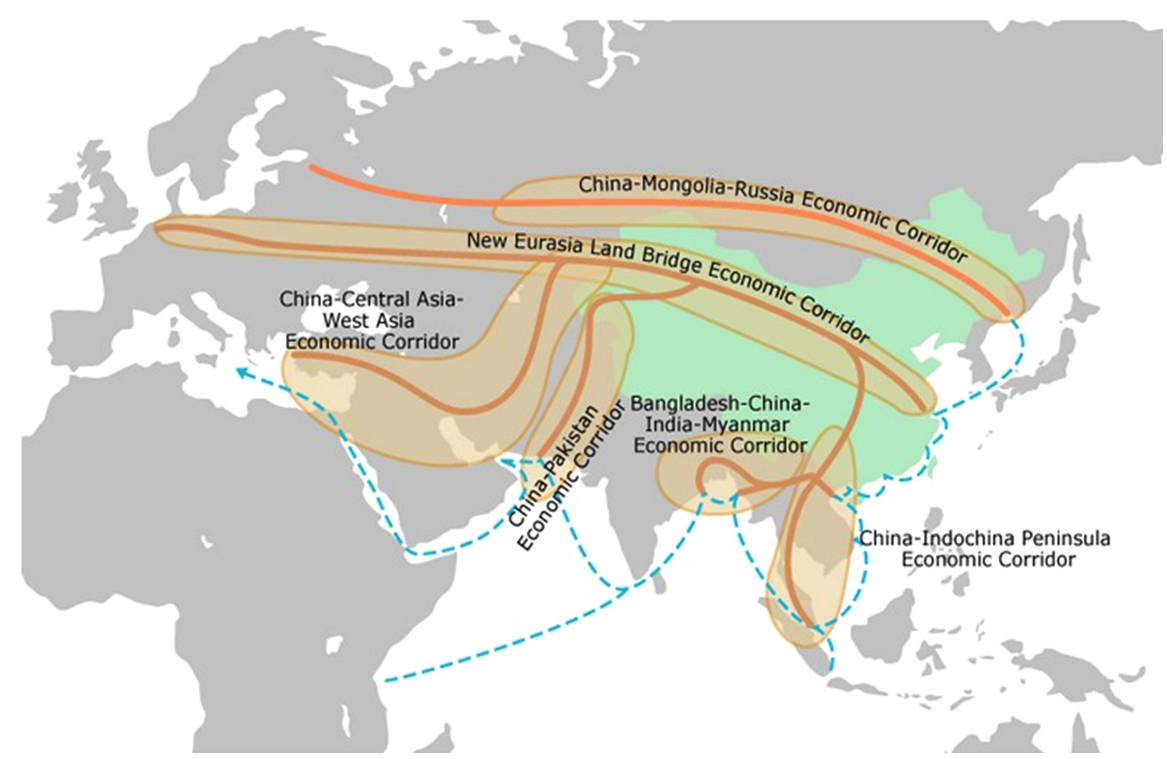

Figure 1. The belt and road initiative. Source:

https://research.hktdc.com/en/article/MzYzMDAyOTg5 (accessed 24 May 2021). 
Xinjiang often travelled by the author is a key axis toward Central Asia, in particular Kazakhstan to observe how works the new Silk Road. The strategic location of Kazakhstan is auspicious toward Russia and Europe [21]. China's main corridors of the new Silk Road toward Central Asia are exemplar in developing the BRI toward Russia and Europe. Around six corridors of the BRI existed in total ten years before, now in 2021 there are eleven corridors along the BRI.

Guangzhou in the Greater Bay Area is China's third-largest city, the capital of Guangdong Province and a thriving commercial center. Its location on the Pearl River and in the proximity of Macau and Hong Kong, has made it a strategic port for centuries.

The potential payoffs of the New Silk Road project are enormous, but its full potential is not yet reached in the Greater Bay Area. However, Chinese business going global and China's role in global economic governance will inevitably grow. No one is to blame for globalization and the risks involved, therefore we need to submit to its dictates and learn to love globalization [22]. The former ASEAN Secretary-General Surin Pitsuwan (1949-2017), since 2002 at the ILO (Appendix). Later, in 2008 he was very supportive of the ASEAN-UN International Pledging Conference held in Yangon on 25 May 2008. And continued to ASEAN up to 2017 when he suddenly passed away, but his memory and intellectual influence will always defend the importance of globalization [23]. China is one of the most important countries always invited to the ASEAN Conferences. ASEAN and Hong Kong SAR are essential concerning the present and future of the BRI.

\section{Conflicts of Interest}

The author declares no conflicts of interest regarding the publication of this paper.

\section{References}

[1] Munn, C. (2009) Anglo-China: Chinese People and British Rule in Hong Kong, 1841-1880. Hong Kong University Press, Hong Kong, 25.

[2] Hayden, P. (2005) Confronting Globalization: Humanity, Justice and the Renewal of Politics. Palgrave Macmillan, New York.

[3] Ervin, J. and Smith, Z.A. (2008) Globalization: A Reference Handbook. ABC Clio, Santa Barbara, 20.

[4] Guthrie, D. (2013) China and Globalization: The Social, Economic and Political Transformation of Chinese Society. 3rd Edition, Routledge, New York, 1.

[5] Patrick, H. (2017) Areas of Cooperation: Patrick Ho Says the Greater Bay Areas (sic) of China and the US Can Pave the Way for Bilateral Trade Cooperation. 16 October, A11.

[6] Devezas, T. and Modelski, G. (2008) The Portuguese as System-Builders. Technological Innovation and Early Globalization. In: Globalization as Evolutionary Process. Modeling Global Change, Routledge, London.

[7] Lewis, D. (2017) China's Global Internet Ambitions: Finding Roots in ASEAN. AEDS 
(Emerald).

[8] Held, D. and McGrew, A. (2007) Globalization/Anti-Globalization: Beyond the Great Divide? 2nd Edition, Polity, Cambridge.

[9] Jones, C.A.G. (2015) Lost in China? Law, Culture and Identity in Post-1997 Hong Kong. Cambridge University Press, Cambridge, 209-210. https://doi.org/10.1017/CBO9781316144916

[10] Cheung, T. (2017) Home Truths Time. SCMP, 17 October, A4. China Policy Seminar Macau, Rui Cunha Foundation, A4.

[11] Xie, F. (2017) Great Expectations: Xie Feng Says Hong Kong Has an Irreplaceable Role in Insuring the Greater Bay Area Reaches Its Full Potential. South China Morning Post, 11 October.

[12] Appadurai, A. (2001) Globalization. Duke University Press, London. https://doi.org/10.1215/9780822383215-001

[13] Bourdieu, P. (1998) Acts of Resistance: Against the New Myths of Our Time. Translated by Richard Nice, Polity Press, Cambridge.

[14] Moore, N. (1990) “The Information Society”, 282. "In Singapore Developments Are Shaped by a Strong, All-Encompassing Framework of Information Policies, Whereas There Are Almost no Formal Policies; Instead Developments Are Shaped by Market Forces Alone".

[15] Callinikos, A. (1999) Social Theory Put to the Test of Politics: Pierre Bourdieu and Anthony Giddens. New Left Review, I/236, July-August.

[16] Overview. https://www.bayarea.gov.hk/en/about/overview.html

[17] Xie, F. (2017) Great Expectation. Hong Kong Has an Irreplaceable Role in Insuring the Greater Bay Area Reaches Its Full Potential. South China Morning Post, 11 October.

[18] https://www.info.gov.hk/gia/general/202103/17/P2021031700706.htm

[19] Marsh, I. (2008) Globalization and Public Opinion in Western Europe and East and Southeast Asia. In: Marsh, I. and Inoguchi, T., Eds., Globalization, Public Opinion and the State: Western Europe and East and Southeast Asia, Routledge, London, $1-25$.

[20] Eric, N. (2017) SCMP, “Kazakhstan Seeks Interest in Assets” 16 October.

[21] Wang, H.Y. and Lu, M. (2016) China Goes Global: How China's Overseas Investment Is Transforming Its Business Enterprises. Palgrave Macmillan/Springer, New York, 172-186. https://doi.org/10.1007/978-1-137-57813-6 8

https://link.springer.com/content/pdf/10.1007\%2F978-1-137-57813-6 8.pdf

[22] Friedman, T. (1999) The Lexus and the Olive Tree: Understanding Globalization. Picador Macmillan, London.

[23] Pitsuwan, S. (2017) Keynote Speech Challenges for ASEAN in the Changing Regional and Global Landscape by H.E. Dr. Surin Pitsuwan Symposium on the 50th Anniversary of ASEAN in Tokyo.

https://www.asean.or.jp/ja/wp-content/uploads/sites/2/2017/06/For-WEB-Symposi um-on-the-50th-Anniversary-of-ASEAN-Verbatim-of-Keynote-Speech-by-Dr.Suri $\underline{\text { n.pdf }}$ 


\section{List of Abbreviations}

$\begin{array}{ll}\text { ASEAN } & \text { Association of South East Asian Nations } \\ \text { BRI } & \text { Belt and Road Initiative } \\ \text { FDI } & \text { Foreign Direct Investment } \\ \text { FMCC } & \text { French Macau Chamber of Commerce } \\ \text { ILO } & \text { International Labour Organisation (UN) } \\ \text { IMF } & \text { International Monetary Fund } \\ \text { MOU } & \text { Memorandum of understanding } \\ \text { OBOR } & \text { One Belt, One Road } \\ \text { SAR } & \text { Special Administrative Region of China } \\ \text { SCMP } & \text { South China Morning Post } \\ \text { SEZ } & \text { Special Economic Zone } \\ \text { SPC } & \text { Supreme People's Court of the People's Republic of China } \\ \text { UN } & \text { United Nations }\end{array}$

\section{Appendix}

The following interview was useful to understand the role of globalization for the world, China, Hong Kong SAR and ASEAN.

I had the honor to interview on globalization the former ASEAN SecretaryGeneral (2008-2012), Surin Pitsuwan at the ICAS10 (International Convention of Asia Scholars) in Chiang Mai on 20 July 2017. He noted the importance of globalization, economic and financial commitments. Dr. Pitsuwan (1949-2017) early and very often stated that globalization is essential during early talks and on the occasion of the 50th anniversary of ASEAN. He said "ASEAN needs to expedite negotiations, encourage developed countries to support technology transfer, as well as global research and development in the region". Long ago, as early as 22 March 2002 when Dr. Pitsuwan was part of the ILO World Commission on Globalization meeting in Geneva. Until his death in 2017, Dr Pitsuwan research and conferences on globalization were a model for the world and China, the secondlargest economy of the world, largely involved on ASEAN. ASEAN always intensify the role of ASEAN Regional Forum (ARF) whose invited members include in particular China mainland and Hong Kong. 